\title{
エスカレータを用いた上方避難に関する実験研究 \\ FEASIBILITY OF UPWARD EVACUATION BY ESCALATOR - AN EXPERIMENTAL STUDY
}

\author{
岡田尚子*, 長谷見雄二**, 森山修治***, 岡 本衣未**** \\ Naoko OKADA, Yuji HASEMI, Shuji MORIYAMA \\ and Emi OKAMOTO
}

\begin{abstract}
A series of on-site experiments are conducted on the upward evacuation by escalator of groups of 50 subjects including 12 simulated aged people. Two escalators, $49.5 \mathrm{~m}$ long and $22 \mathrm{~m}$ tall one, and $12.3 \mathrm{~m}$ long and $5.7 \mathrm{~m}$ tall one with parallel stairs in a large convention facility in downtown Tokyo, were used. The experiments revealed the following.

1. Upward walking velocity on a still escalator, $0.78-0.79 \mathrm{~m} / \mathrm{s}$ for normal subjects, is nearly identical with that on normal stairs.

2. Upward walking velocity on an escalator running at $0.50 \mathrm{~m} / \mathrm{s}$ is reduced by $5-10 \%$ from that on a still escalator.

3. Upward walking velocity is virtually independent from the distance from the entrance within the range of $22 \mathrm{~m}$ in height for normal and simulated aged pedestrians in spite of the height and length of each step significantly larger than those of stairs.

4. Effective flow coefficient at the entrance is around 1.15 persons $/ \mathrm{ms}$ for a still escalator and $1.78 \mathrm{p} / \mathrm{ms}$ for a one running at $0.50 \mathrm{~m} / \mathrm{s}$.

5. The effective flow coefficient at the entrance of an escalator is reduced by the increase of the escalator length for the local congestions generally seen in long escalators.
\end{abstract}

Keywords : Escalator, Underground, Group, Fire, Evacuation, Instant-senior エスカレータ，地下，群集，火災，上方避難，インスタントシニア

\section{1. 研究の背景と目的}

地下空間の大規模化や地下鉄道の大深度化、交通機関における利 用者数の増加、バリアフリー環境の普及促進等に伴い、現在、エス カレータは公共施設における鉛直方向の歩行者輸送の一般的な手段 となってきている。こうしたエスカレータの多用を背景に、階段を 見つけにくい施設や、エスカレータを使用せずには地上に辿り着く ことが困難な深い地下鉄駅なども多く出現している。こうした施設 で火災等の災害時にエスカレータを避難に使わざるを得なくなる可 能性は大きいが、現在、エスカレータは建築基準法上、避難施設に 該当しないため、災害時にどう利用すべきかはほとんど検討されて おらず、避難時のエスカレータの適切な操作方法、一般の階段に比 ベてステップの蹴上げ及び踏み面寸法の大きいエスカレータの歩行 可能性や危険性、入口及び出口付近で不均一な䟣上げが与える影響、 ステップ幅の狭いエスカレータ上での追い抜き行動上の特徵等、エ スカレータを用いた避難には未だ多くの検討課題がある。また、現 在、エスカレータは、非常時には停止させることを前提としており、 避難活用を検討する場合も、停止した状態で階段の代わりに使うこ とを想定することが多いが 2)、災害時に避難すべき方向に走行させ
て安全に利用することができれば、大深度地下等において、避難時 間の短縮に大きな効果があるだけでなく、階段での避難に困難があ る高齢者や身体障害者の避難にも有効であると考えられる。

本研究は、以上を踏まえ、災害時にエスカレータが避難に使われ る可能性が特に高い場合として地下駅等の地下空間を想定し、高齢 者等、歩行速度の遅い避難者も混在する群集の避難への利用可能性 を具体的に検討する上で必要な避難行動諸特性を、実験的に把握し ようとするものである。実験は、実際の地上施設のエスカレータを 用い、擬似高齢者を含む群集について、エスカレータ上昇歩行速度 並びにエスカレータ入口での被験者の有効流動係数等、避難計画に 必要な基礎データの把握を行った。尚、実験では下降歩行実験も行 ったが、本論文では対象外とする。

\section{2. 実験方法}

\section{1 概要}

実験は、都内大型施設にある長さ等の異なる 2 つのエスカレータ を用いて、2007 年 8 月 15 日午前 9 時から午後 5 時の間に、通常照 明及び空調のある状態で実施した。被験者は大学生 50 名を公募し

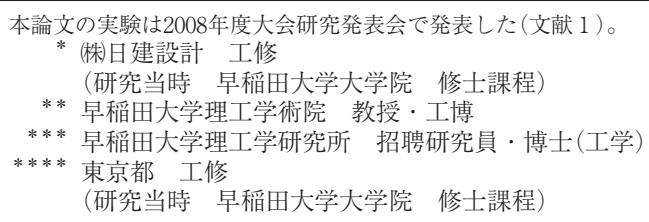

Nikken Sekkei Ltd., M. Eng.

(Formerly Graduate School, Waseda University)

Prof., Department of Architecture, Waseda University, Ph. D.

Visiting Researcher, RISE, Waseda University, Ph. D.

Tokyo Metropolitan Government, M. Eng.

(Formerly Graduate School, Waseda University) 
た。実験は、被験者をエスカレータ前に整列させ、スタートの合図 でエスカレータに流入を開始し、エスカレータを通過し終えるまで の行動を 1 回とし、エスカレータの稼動・停止状態、被験者の配置、 階段使用の有無等、条件と場所を変えて 25 回実施し、各所に設置 したビデオカメラの映像より、各被験者の歩行時間の測定・軌跡の 把握、エスカレータ入りロでの通過人数の測定、エスカレータ上で の歩行者密度の測定等を行った。

\section{2 用語の定義}

用語の定義を表 1 に示す。

\section{3 被験者の条件}

被験者は学生 50 名（男性 35 名、女性 15 名／平均年齢 21 歳）で あり、うち 12 名 $(24 \%)$ はインスタントシニア ${ }^{3)}$ を装着させた。イン スタントシニアは、健常者が装着することにより、概补 75 歳から 80 歳の高齢者と同等の体力及び感覚状態を擬似体験できる装備で あり、本研究では装着者を群集に混在させることで、歩行速度の遅 い歩行者が群集全体の歩行に及ぼす影響を把握する。装着者には、 過去に装着体験のある者のみを選定したが、実際の高齢者を被験者 としなかったのは事故の危険性を考慮したためであり、インスタン トシニアを群集避難行動実験に使用した場合の高齢者能力の再現性
は、廊下等、水平面の歩行については実験的に検証されている ${ }^{3)}$ 。 本論では、以下、インスタントシニア装着者を「シニア」と略す。 被験者は安全の為、長袖及び長ズボン、運動靴を全員に着用させ、 健常者には軍手を着用させた。被験者識別の為、ナンバープレート 付の色帽子を着用させた。

\section{4 実験に使用したエスカレータ}

高さ約 $22 \mathrm{~m}$ 、長さ約 $49.5 \mathrm{~m}$ の「長距離エスカレータ(写真 1 、図 1 、 表 2)」と、高さ約 $5.7 \mathrm{~m}$ 、幅 $2.5 \mathrm{~m}$ の階段が併設された「短距離エスカ レータ(写真 2 、図 2、表 2)」の 2 種類のエスカレータを使用した。 以下、前者における実験を「長距離エスカレータ実験」、後者におけ る実験を「短距離エスカレータ実験」と呼ぶ。両者の幅は若干異な るが、概釉ステップ幅 $1 \mathrm{~m}$ 、手寸り間距離 $1.2 \mathrm{~m}$ であり、2 名並行し て歩行できる。長距離エスカレータは、深層地下鉄駅で使われてい る非常に長いエスカレータを再現することを目的としており、エス カレータ端部からの歩行距離に応じて被験者の歩行速度が変化する

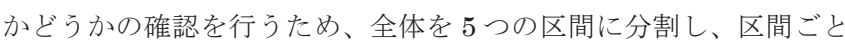
の歩行速度 (移動速度) を計測した。短距離エスカレータ実験では、 図 2 のように階段が併設されていることを活用し、両者の歩行行動 を比較すると共に、エスカレータ・階段の選択性の把握を試みた。

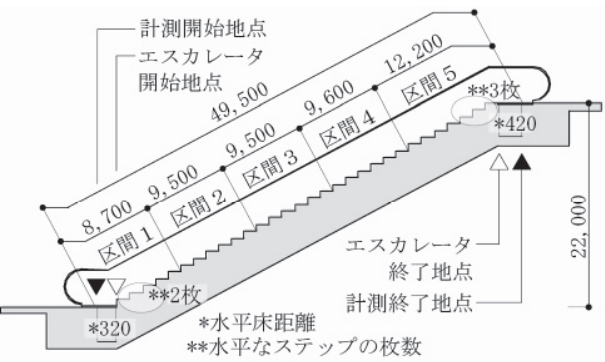

図 1 （1）長距離エスカレータ断面図 $(\mathrm{mm})$

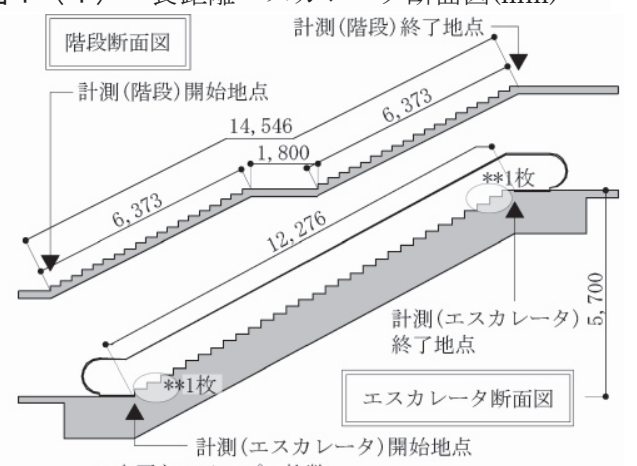

**水平なステップの枚数

図 2（1）短距離エスカレータ断面図 $(\mathrm{mm})$

表 1 用語の定義



図 1 （2）長距離エスカレータ平面図 $(\mathrm{mm})$
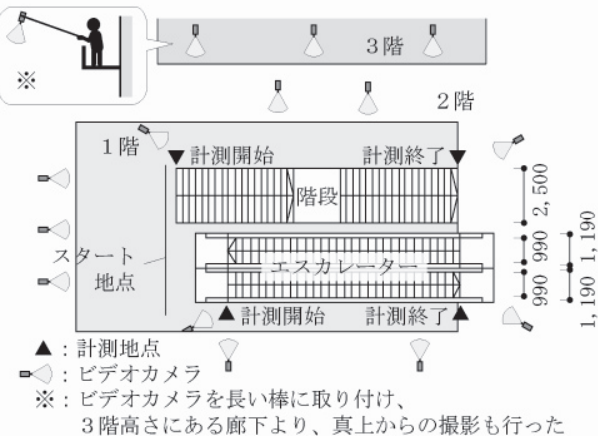

図 2（2）短距離エスカレータ平面図 $(\mathrm{mm})$

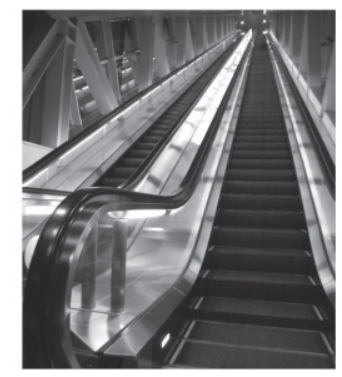

写真 1 長距離エスカレータ

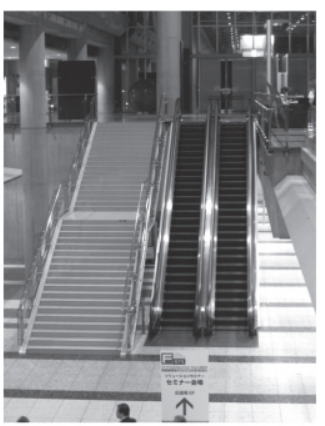

写真 2 短距離エスカレータ 表 2 エスカレータ・階段寸法 $(\mathrm{mm})$

\begin{tabular}{|c|c|c|c|}
\hline 用語 & 単位 & \multicolumn{2}{|l|}{ 定義 } \\
\hline $\begin{array}{l}\text { 単位幅あたり } \\
\text { 通過人数 }\end{array}$ & $($ 人 $/ \mathrm{s} \cdot \mathrm{m})$ & \multicolumn{2}{|c|}{ 入口等において、単位時間・単位幅あたり通過する人数。 } \\
\hline 入口通過人数 & (人/s) & \multicolumn{2}{|c|}{$\begin{array}{l}\text { 入口等を単位時間に通過する人数。実測值等であり、入口幅で割って、単位幅通 } \\
\text { 過人数、流動倸数等を定する。 }\end{array}$} \\
\hline 流動係数 & $($ 人 $/ \mathrm{s} \cdot \mathrm{m})$ & \multicolumn{2}{|c|}{$\begin{array}{l}\text { 入口等において通過前に滞留が生じ、通過後に滞留が生じない条件で、単位時 } \\
\text { 間・単位幅あたり通過できる人数。開口部等自体の歩行者通過能力を表す。 }\end{array}$} \\
\hline 有効流動倸数 & (人/s $\cdot \mathrm{m})$ & \multicolumn{2}{|c|}{$\begin{array}{l}\text { 入口等において通過前、通過後の両方に人が滞留する場合に単位時間・単位幅あ } \\
\text { たり通過できる人数。通過後の滞留の状態の影響を受け、流動係数よりも小さい } \\
\text { 値となる。告示避難安全検証法を含め、避難計算等で一般に使われている。 }\end{array}$} \\
\hline 歩行者流量 & (人/s) & \multicolumn{2}{|c|}{ エスカレータ上やエスカレータ前の空間を単位時間に通過する人数。 } \\
\hline 搬送可能流量 & $($ 人 $/ \mathrm{s})$ & \multicolumn{2}{|c|}{ 単位時間にエスカレータが搬送可能な人数。 } \\
\hline 歩行速度 & $(\mathrm{m} / \mathrm{s})$ & \multicolumn{2}{|c|}{ 単位時間に歩行する距離。 } \\
\hline \multirow{3}{*}{ 移動速度 } & \multirow{3}{*}{$(\mathrm{m} / \mathrm{s})$} & \multicolumn{2}{|c|}{ 静止した床面から測った歩行者が移動する速度。 } \\
\hline & & エスカレータ停止時 & 「「歩行者の歩行速度」に一致。 \\
\hline & & エスカレータ稼動時 & \begin{tabular}{|l} 
「歩行者の歩行速度」と「エスカレータ走行速度 \\
(通常速度 $0.5 \mathrm{~m} / \mathrm{s}$ )」の合計值に一致。
\end{tabular} \\
\hline 歩行者密度 & $\left(\right.$ 人 $\left./ \mathrm{m}^{2}\right)$ & \multicolumn{2}{|c|}{ 進行方向 (長さ方向) 平面内における単位面積当りの人数。 } \\
\hline
\end{tabular}

入口枚数 · 入口において水平なステップの枚数 $* 4$ 出口枚数: 出口において水平なステップの枚数 


\section{5 実験条件の設定}

本実験では、「エスカレータの稼動・停止状態」「被験者の配置」

「階段の使用（短距離エスカレータ実験のみ）」「エスカレータ前手 摺設置（短距離エスカレータ実験で実施）」の条件を変化させ、計 25 ケースの実験を計画した。表 3 に実験ケース毎の条件を示す。

\section{（1）エスカレータの状態}

実験は、エスカレータが停止している状態と通常速度 $(30 \mathrm{~m} / \mathrm{s}=$ $0.50 \mathrm{~m} / \mathrm{s})$ で上方に動いている状態の 2 つの状態で実施した。

\section{（2）被験者の配置}

まず、エスカレータ停止・稼動状態でそれぞれ、被験者を単独歩 行させ、被験者個々の能力の把握を行ったうえ、健常者及びシニア を混在させ、群集で歩行させた。表 4（1）に群集実験時の被験者配 置を示す。配置 $\mathrm{A}$ (写真 3) は、被験者を正方形に並べ、シニアを全体 にランダムに配置しており、歩行速度の遅い歩行者（シニア）が全 体の歩行に及ぼす一般的な影響を把握すると共に、エスカレータ入 口に歩行者が殺到した場合の有効流動係数の把握を行うことを目的 とする。配置 B は、被験者を 2 列に整列させ、シニアを両列にラン ダムに配置したもので、配置 A と、歩行速度並びにエスカレータ入 口での単位幅あたり通過人数を比較し、整列がエスカレータ上の群 集歩行に及ぼす影響を把握する。配置 $\mathrm{C}$ は、被験者を 2 列に整列さ せるが、シニア全員を右列に配置して、配置 B と、歩行速度並びに エスカレータ入口での単位幅あたり通過人数を比較し、歩行速度の 遅い歩行者（シニア）を片側に限定した場合の群集歩行行動への影 響を把握することを目的としている。また、全体を通して、ステッ プ幅の狭いエスカレータ上でシニアが群集歩行をどう決定付け、シ ニアを健常者はどのように追い越すか等の把握を試みた。

表 4（1） 被験者配置

\begin{tabular}{|c|c|c|c|}
\hline 単独 & 1 列に=整列させ、一 & 隔を開けて順に歩行 & \\
\hline A & $\begin{array}{l}\text { 群集歩行 } \quad(7 \times 7 \text { ランダム配置) } \\
\text { インスタントンニア } 12 \text { 人 }(24 \%) \\
\text { 表4 } 4 \text { (1) 及び表4 } 4(2) \text { で共通 }\end{array}$ & 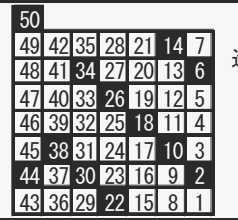 & $\begin{array}{c}\text { 進行方向 } \\
\Rightarrow \\
\Rightarrow\end{array}$ \\
\hline B & 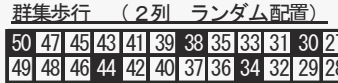 & 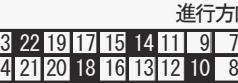 & 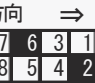 \\
\hline C &  & 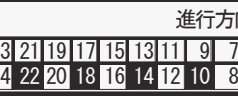 & 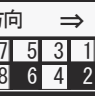 \\
\hline
\end{tabular}

表 4 (2) 手摺設置時の様子

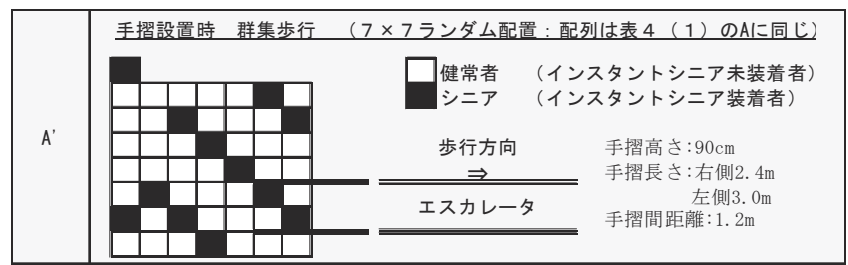

表 5 実験器具一覧

\begin{tabular}{|c|c|c|c|}
\hline 使用器具等 & & 個数 & 備考 \\
\hline 色帽子 & 50 & （個） & \multirow{2}{*}{$\begin{array}{l}\text { 被験者は前・上・後ろの3箇所にナン } \\
\text { バープレートの付いた色帽子 (5色)を着 } \\
\text { 用。色と番号は被験者識別のため。 }\end{array}$} \\
\hline ナンバープレート & 150 & （個） & \\
\hline 軍手 & 38 & (セット) & 健常者が転倒時ケガ防止のために着用 \\
\hline インスタントシニア & 12 & (セット) & \\
\hline ポールパーテーション & & (個) & エスカレーター前手摺再現時に使用 \\
\hline ビデオカメラ & 14 & (台) & \\
\hline
\end{tabular}

（3）階段の併用（短距離エスカレータ実験のみ）

エスカレータは、ステップの蹴上げと踏面寸法(200-400mm)が一 般の階段(150-300mm)より大きいうえ、出入口付近の蹴上げ寸法が 不均一であるため、階段に比べて歩き辛いと予想した。そこで、階 段と比べて歩行速度が低下したり、入口付近で歩行者の滞留が生じ 易くなる可能性を検討するため、階段と停止状態のエスカレータに おける歩行の比較を行った（ケース７と 10、ケース 9 と 18)。また、 エスカレータと階段前に、被験者を配置 A で整列させ、スタートの 合図で任意に経路を選択させて上昇歩行させる実験も行い(ケース 14、15)、経路選択の偏りやエスカレータの状態による経路選択の 変化の把握を試夕た(写真 4 )。

\section{（4）エスカレータ前手摺の設置（短距離エスカレータにて実施）}

駅プラットホームのエスカレータ前に設置されている手摺(写真 5)は、通勤時間帯等の混雑時に、エスカレータ入口に殺到する歩行 者の流れを整流するためのものであるが、人の流れを整流すること で、流動係数の改善にも効果がある可能性を考えた。そこで、この 効果の有無・程度を検証するため、エスカレータ前に手摺に模した ポールパーティションを設置し、配置 A で群集を流入させた(表 4 (2)、写真 6)。配置 A で手摺付けを行い、手摺のない場合の配置 A、 配置 B と、エスカレータ入口での単位幅あたり通過人数を比較する ことにより、手摺がエスカレータを使用する群集避難行動に与える 影響を把握する（ケース 18 と 20 、ケース 19 と 21）。

表 3 実験ケース

\begin{tabular}{|c|c|c|c|c|c|}
\hline & ケース & エスカレーター & 階段 & 被験者の配置 & 備考 \\
\hline \multirow{3}{*}{ 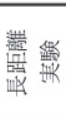 } & 1 & 停止 & & \multirow{2}{*}{ 単独 } & \\
\hline & 3 & 稼動 & & & \\
\hline & 5 & 停止 & & A & \\
\hline \multirow{11}{*}{ 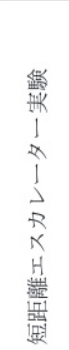 } & $\frac{6}{7}$ & 稼動 & \multirow[b]{2}{*}{ 使用 } & 単独 & \\
\hline & 9 & & & $\mathrm{~A}$ & \\
\hline & $\frac{10}{12}$ & $\begin{array}{l}\text { 停止 } \\
\text { 䅗動 }\end{array}$ & & 単独 & \\
\hline & $\frac{12}{14}$ & $\begin{array}{l}\text { 稼動 } \\
\text { 侣止 }\end{array}$ & \multirow[b]{2}{*}{ 使用 } & \multirow[b]{2}{*}{ A } & \\
\hline & 15 & 稳動 & & & 䅅選伊意 \\
\hline & 18 & 停止 & & \multirow{2}{*}{ A } & \\
\hline & 19 & 橡動 & & & \\
\hline & 20 & 停止 & & \multirow[t]{2}{*}{$A^{\prime}$} & 手摺設置 \\
\hline & 21 & 稼動 & & & \\
\hline & $\frac{22}{23}$ & $\begin{array}{l}\text { 停止 } \\
\text { 稼動 }\end{array}$ & & B & \\
\hline & 24 & 停止 & & \multirow[b]{2}{*}{ C } & \\
\hline & 25 & 稼動 & & & \\
\hline
\end{tabular}

注(1)ケース 16 および 17 はビデオ映像が不鮮明のため未解析

注(2)ケース $2 、 4 、 8 、 11$ および 13 は、下降歩行実験であるため、本論文では対象外とする 注(3)ケース 6 と 7 の間に 1 時間ほどの休瓜を設けた

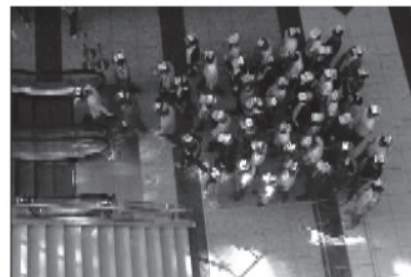

写真 3 配置 $\mathrm{A}$

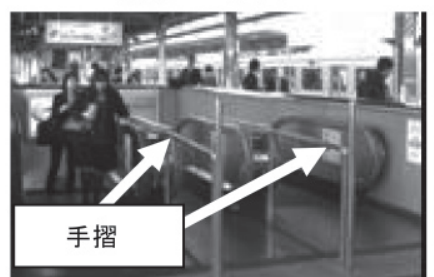

写真 5 JR山手線新橋駅

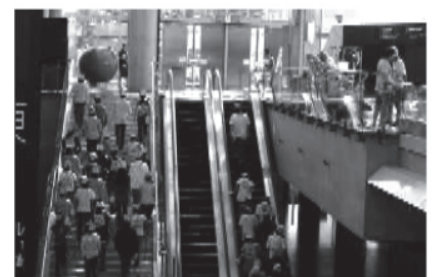

写真 4 経路選択様子

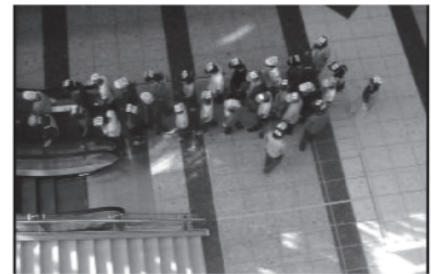

写真 6 手摺設置時の流動 


\section{6 測定の項目と方法}

実験に使用した用具を表 5 に示す。

\section{(1) 移動速度}

本論文では、「静止した床面から測った歩行者が移動する速度」を 「移動速度」と定義する(表 1)。エスカレータ停止時の移動速度は、 「歩行者の歩行速度」に一致し、エスカレータ稼動時は、「移動速度」 と「エスカレータ走行速度(通常速度 $0.50 \mathrm{~m} / \mathrm{s}$ )」の差が「歩行者の歩 行速度」となる。移動速度は、エスカレータ上で被験者の移動を観 測した範囲の長さ (移動距離 $(\mathrm{m}))$ を、移動時間 $(\mathrm{s}) て ゙$ 除して算定した。 移動時間は各所に設置したビデオカメラの映像より測定した。平均 移動速度」は健常者 38 人、シニア 12 人、それぞれ属性ごとの平均 值であり、「単独移動速度」は、単独で歩行した際の移動速度をまた、

「群集移動速度」は群集で歩行した際の各被験者の移動速度を表す。 （2）エスカレータ 途中区間ごとの移動速度

エスカレータのステップの蹴上げ及び踏み面寸法は、一般的な階 段よりも大きいため、疲労が生じ易いと予想した。特に、大深度地 下駅等にある長距離のエスカレータを上昇する場合、疲労から途中 で歩行速度が低下したり、歩行を停止する歩行者が発生すると、群 集避難に著しい影響を与える可能性がある。そこで、出発地点から の歩行距離に応じて、被験者の移動速度に変化が現れるかどうかを 確認するため、長距離エスカレータを $5 つ$ の間に分割し、区間ご との移動速度を計測し、比較した。区間の境界線上には、被験者の 位置確認のため帯状の垂れ幕(図 1 、写真 7 )を設置した。区間 1 と区 間 5 はそれぞれ、下階・上階の床に接する緩勾配部分を含む。

\section{（3）エスカレータ入口での単位幅当たり通過人数}

「単位幅当たり通過人数 $(人 /(\mathrm{s} \cdot \mathrm{m}) 」$ は、最初と最後に流入した 5 人ずつを除いた 40 人に着目し、入口通過人数(40人)を、 40 人のエ

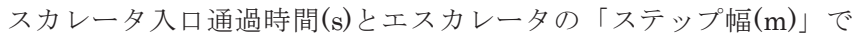
除して算出した。通過時間は、ビデオ映像より測定した。

\section{（4）歩行者密度}

「進行方向(長さ方向)平面内における単位面積当りの人数」を「歩 行者密度」と定義する。本論文で報告する「歩行者密度 $\left(\right.$ 人 $\left./ \mathrm{m}^{2}\right) 」$ は、 ケース 18 と 19 において、先頭部分を除いた群集について、連続す る 10 名前後の被験者に着目し、その人数(人)をその人数の占有する 面積 $\left(\mathrm{m}^{2}\right)$ で除した值であり、約 7 名間隔で 4 回繰り返し算出し(例： $7 \sim 16$ 番目、14 23 番目、 $21 \sim 30$ 番目、 $28 \sim 37$ 番目)、 4 回の平均 值より求めた。占有面積はビデオカメラ映像の静止画より占有段数 を測定し、それをもとに算出した。

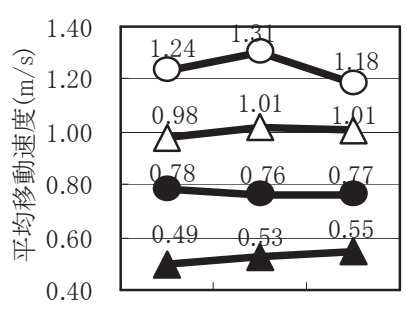

区間2 区間3 区間4

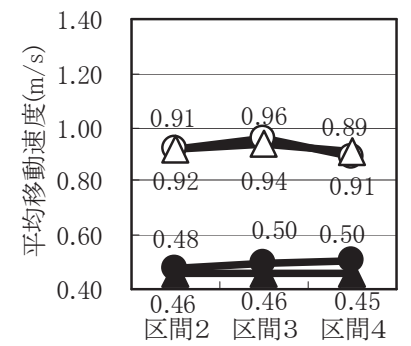

(b) 沪? 12 名の平均移動速度

（a）健常者 38 名の平均移動速度

\section{稼動/単独 $\triangle$ 稼動/群集 \\ 停止/単独 (ケース 1) \\ $\sim \underset{\text { 停止/群集 }}{\text { ケース } 3)}-$ (ケース 5) 乙}

\section{3. 実験結果と考察}

実験より得られた平均移動速度を表 6 に、エスカレータ入口での 単位幅当たり通過人数を表 7 に、また、歩行者密度を表 8 に示す。

表 6 エスカレータ上の平均移動速度 $(\mathrm{m} / \mathrm{s})$

長距離エスカレータ $* 1$ 全長（区間 1 から区間 5 の合計）

\begin{tabular}{|l|c|c|c|c|}
\hline & $\begin{array}{c}\text { ケース 1 } \\
\text { 【単独 } / \text { 停止】 }\end{array}$ & $\begin{array}{c}\text { ケース 3 } \\
\text { 【単独 / 稼動】 }\end{array}$ & $\begin{array}{c}\text { ケース 5 } \\
\text { 【A / 停止】 }\end{array}$ & $\begin{array}{c}\text { ケース 6 } \\
\text { 【A / 稼動】 }\end{array}$ \\
\hline \hline 健常者 & 0.79 & 1.26 & 0.54 & 1.01 \\
\hline シニア & 0.50 & 0.93 & 0.47 & 0.93 \\
\hline
\end{tabular}

短距離エスカレータ

\begin{tabular}{|l|c|c|c|c|}
\hline & $\begin{array}{c}\text { ケース 1 0 } \\
\text { 【単独／停止】 }\end{array}$ & $\begin{array}{c}\text { ケース 1 2 } \\
\text { 【単独／稼動】 }\end{array}$ & $\begin{array}{c}\text { ケース 1 8 } \\
\text { 【A／停止】 }\end{array}$ & $\begin{array}{c}\text { ケース 1 9 } \\
\text { 【A／稼動】 }\end{array}$ \\
\hline \hline 健常者 & 0.78 & 1.21 & 0.54 & 0.95 \\
\hline シニア & 0.53 & 0.93 & 0.48 & 0.90 \\
\hline \hline
\end{tabular}

\begin{tabular}{|c|c|c|}
\hline & $\begin{array}{c}\text { ケース } 20 \\
\text { 【A整流/停止】 }\end{array}$ & $\begin{array}{c}\text { ケース } 21 \\
\text { 【A整流/稼動】 }\end{array}$ \\
\hline 健常者 & 0.51 & 1.03 \\
\hline シニア & 0.46 & 0.92 \\
\hline
\end{tabular}

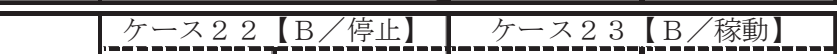

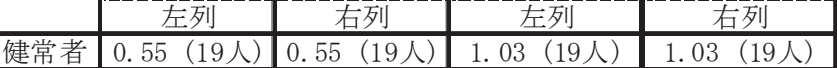
\begin{tabular}{|l|ll|ll|ll|ll|} 
シニア & 0.49 & (6人) & 0.53 & (6人) & 0.96 & (6人) & 0.98 & (6人) \\
\hline
\end{tabular}

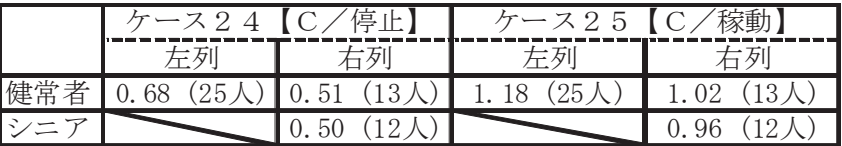

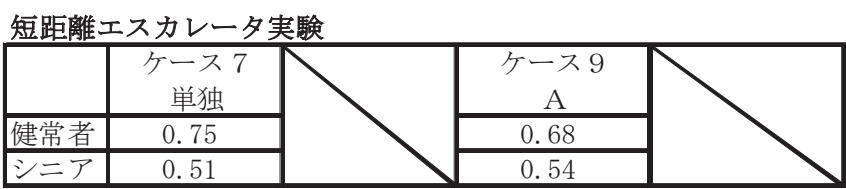

*2 表内は、ケース $22 \sim 25$ を除き、健常者 38 名、シニア 12 名の平均值

表 7 エスカレータ人口での単位幅当たり通過人数 $(人 /(\mathrm{s} \cdot \mathrm{m}))$

長距離エスカレータ

\begin{tabular}{|c|c|c|c|}
\hline \multicolumn{2}{|c|}{ 停止時 配置（ケース） } & \multicolumn{2}{|c|}{ 稼動時 配置 (ケース) } \\
\hline 1.07 & A（ケース5) & 1.62 & $\mathrm{~A}($ ケース 6$)$ \\
\hline \multicolumn{4}{|c|}{ 短距離エスカレータ } \\
\hline \multicolumn{2}{|c|}{ 停止時 配置（ケース） } & \multicolumn{2}{|c|}{ 稼動時 配置（ケース） } \\
\hline 1.16 & $\mathrm{~A}($ ケース 18$)$ & 1.78 & $\mathrm{~A}($ ケース19) \\
\hline 1.12 & $\mathrm{~A}^{\prime}$ 手摺 (ケース20) & 1.64 & A'手摺(ケース 21) \\
\hline 1.15 & B (ケース 22$)$ & 1.63 & $\mathrm{~B}($ ケース23) \\
\hline 1.26 & $\mathrm{C}($ ケース 24$)$ & 1.68 & C (ケース25) \\
\hline
\end{tabular}

*3 先頭と最後尾の5名を除いた40名より算出

*4 幅はエスカレータのステップ幅で定義

表 8 エスカレータ上の歩行者密度 $\left(\right.$ 人 $\left./ \mathrm{m}^{2}\right)$

短距離エスカレータ

\begin{tabular}{|c|c|}
\hline 停止時 配置（ケース） & 稼動時 配置 (ケース) \\
\hline \begin{tabular}{l|l}
1.98 & $\mathrm{~A}($ ケース 18$)$
\end{tabular} & $\mathrm{A}($ ケース19) \\
\hline
\end{tabular}

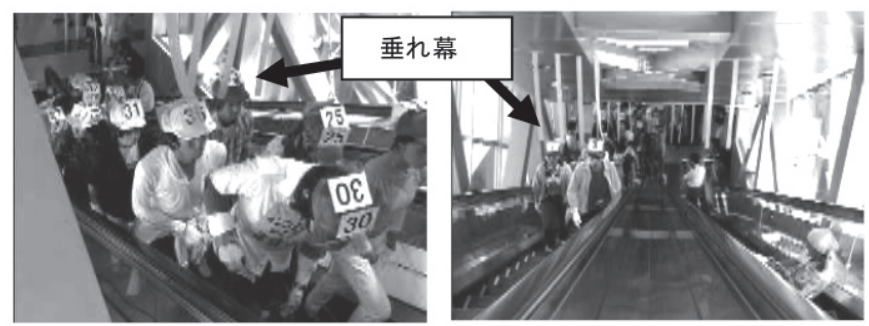

写真 7 長距離エスカレータにおける垂れ幕の様子 


\section{1 移動速度及び歩行速度}

エスカレータ停止時の単独移動速度は、健常者が約 $0.8 \mathrm{~m} / \mathrm{s}$ 、シニ アが約 $0.5 \mathrm{~m} / \mathrm{s}$ であり、エスカレータ稼動時(通常速度 $0.50 \mathrm{~m} / \mathrm{s}$ )の単 独移動速度は、健常者が約 $1.2 \mathrm{~m} / \mathrm{s}$ 、シニアが約 $0.9 \mathrm{~m} / \mathrm{s}$ であった(表 6)。また、群集移動速度(配置 A)に関しては、健常者、シニア、共 に、エスカレータ停止時は約 $0.5 \mathrm{~m} / \mathrm{s}$ 、エスカレータ稼動時は $0.9 \sim$ $1.0 \mathrm{~m} / \mathrm{s}$ であった。エスカレータを稼動させると、停止時に比べ移動 速度は $0.4 \mathrm{~m} / \mathrm{s}$ 余増加し、シニアが $24 \%$ 混在する群集の歩行時は、 全体の歩行速度がシニアの歩行速度にほぼ一致するという見解が得 られた。以下、測定結果について検討する。

（1）歩行距離に応じた移動速度の変化（図 3)

長距離エスカレータ実験における、区間 $2 \sim 4$ の平均移動速度を 比較した結果、エスカレータの状態や単独・群集等の歩行の状態に よらず、健常者もシニアも、歩行距離の増加に伴う移動速度の低下 は見られず、移動速度はほぼ一定であることが分かった(図 3)。また、 長距離エスカレータ実験と短距離エスカレータ実験の移動速度は、 その他の歩行条件が同じ場合、ほぼ一致しており、この程度の長さ のエスカレータでは、歩行距離による移動速度の違いは生じないと 判断できる。この傾向はシニアでも認められるから、日常的な歩行 速度や歩行上の障害・制約条件にはよらないと考えられる。但し、 インスタントシニアで長距離歩行時の高齢者の疲労まで再現できる かどうかは明らかではなく、実際の高齢者の歩行行動に対する距離 の影響については今後の検討が必要である。

（2）エスカレータ稼動による移動速度の変化（表 6)

エスカレータを速度 $0.50 \mathrm{~m} / \mathrm{s}$ で稼動させると、平均移動速度は停 止時に比べ、0.40〜0.47 m/s 増加することが確認できた。どの実験 でも、エスカレータ稼動時の歩行速度が、停止時より僅かではある が、低下する結果となったのは興味深い。

（3）シニア (遅い歩行者) が全体の歩行に及ぼす影響（図 4，表 6) 短距離エスカレータ停止時の単独移動速度(ケース 10) と群集移動 速度(配置 $\mathrm{A} \sim \mathrm{C}$ 、ケース 18,22,24)を被験者毎に比較した結果を整 理して、図 4 に示寸。シニアは単独歩行時に比べて群集歩行時の移 動速度がやや低下寸るものの、その変化は僅かであるのに対し、健 常者は、先頭の被験者を除き全体的に移動速度が低下寸る。

配置 $\mathrm{A}$ 及び $\mathrm{B}$ では、健常者の移動速度は、ほぼシニアの移動速度 に拘束され、ステップ幅が並行歩行に余裕のないエスカレータ上に シニアが点在すると、後続の被験者がシニアの影響を受ける様子を 確認できる。特にシニアが 2 名横に並んだ場合は後続の歩行者が前 方のシニアを追い抜けないことが顕著であり、シニアが並んでいな ければ追い抜きを行う被験者も複数、存在した。配置 Cは、シニア を右列のみに配置したため、左列の健常者はシニアの影響を受けず に歩行でき、混在時に比べて移動速度の低下を抑えることができた （図 4(c) 左列健常者 $0.68 \mathrm{~m} / \mathrm{s}$ 、右列健常者 $0.51 \mathrm{~m} / \mathrm{s}$ 、右列シニア $0.50 \mathrm{~m} / \mathrm{s}$ )。エスカレータ稼動時にも同様の結果が得られた。 なお、門倉らによる停止エスカレータ上の群集上昇歩行実験 ${ }^{2)}$ によ ると、高齢者やシニアを混在させた時の歩行速度は 1 層分のエスカ レータでは平均 $0.72 \mathrm{~m} / \mathrm{s} 、 4$ 層分の長距離エスカレータでは平均 $0.70 \mathrm{~m} / \mathrm{s}$ であり 注 1 、本実験の配置 A,B の場合よりかなり大きく、配 置 $\mathrm{C}$ の場合に近い。本実験では、被験者 50 名中 12 名がシニアであ るのに対し、門倉らの実験では、1 層分の実験では、被験者 41 名中
高齢者が 6 名、 4 層分の実験では被験者 81 名中シニアが 2 名とな っていて、高齢者・シニアの割合が小さいから、シニアの追い抜き の頻度は本実験よりも少なく、シニアが群集全体の歩行に及ぼす影 響も相対的に軽微だったと考えられる。これより、歩行速度の異な る集団がランダムに混在する群集の歩行速度は、混在率の影響を受 け、本実験のシニア混在率 $24 \%$ では、ほぼ、歩行速度の遅い集団の 影響が群集全体を支配すると判断できる。

\section{2 歩行者密度およびエスカレータ歩行者流量（表 8、表 9) \\ （1）歩行者密度（表 8、図 5)}

歩行者密度を、エスカレータ入口での単位幅あたり通過人数の多 い配置 $\mathrm{A}$ で求めると、エスカレータ停止時が 1.98 人 $/ \mathrm{m}^{2}$ 、稼動時が 1.95 人 $/ \mathrm{m}^{2}$ と、停止時の方が僅かに密度が高いものの、ほぼ、 2.0 人 $/ \mathrm{m}^{2}$ であり、大きな差は見られない(表 8)。

エスカレータ上を定常的に歩行する上での、エスカレータ上の歩 行者密度の上限は、ステップ 2 段当り 2 人、 2.5 人 $/ \mathrm{m}^{2}($ 図 $5(1))$ と考 えられるが、これは、”前の歩行者が上の段に足を踏み出すと同時に、 後続の歩行者も上の段に足を踏み出す”という状態が、エスカレータ 上の全歩行者で継続的に行われる場合であり、シニアの混在する群 集では、ほぼ不可能と考えられる。実験值 2.0 人 $/ \mathrm{m}^{2}$ は、2 段当り約 1.6 人(図 5(2))であり、シニア混在時にエスカレータ上を円滑に歩行 できる密度の上限を表すと解釈できる。

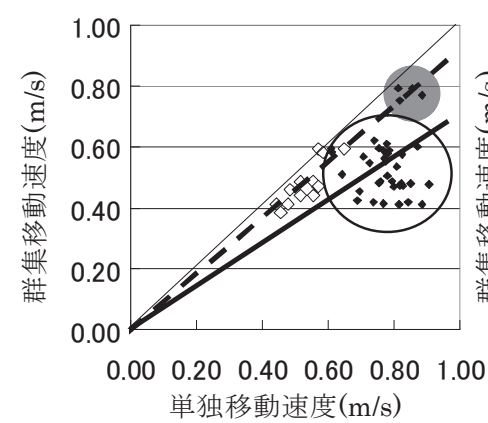

(a) 配置 $\mathrm{A}$ 歩行(ケース 18)

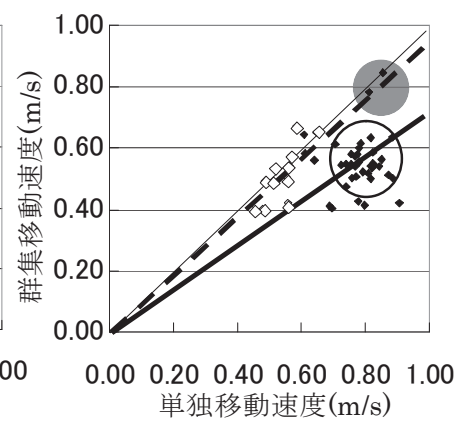

(b) 配置 B 歩行(ケース 22)
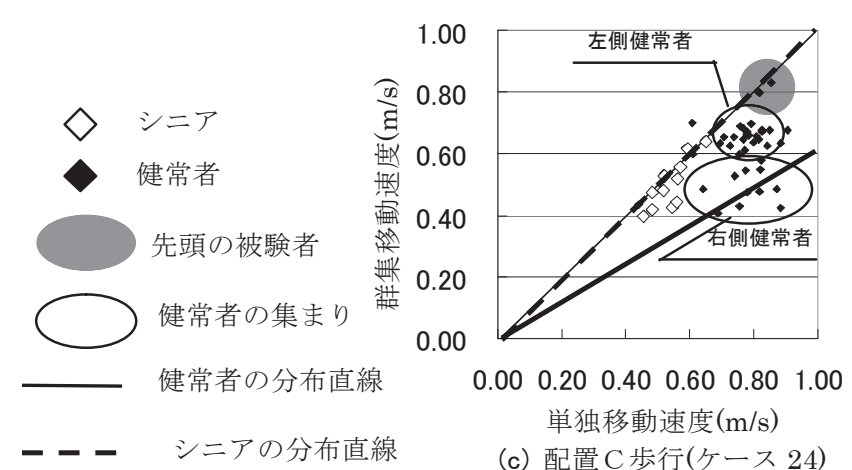

図 4 短距離エスカレータ停止時の単独移動速度と群集移動速度の比較

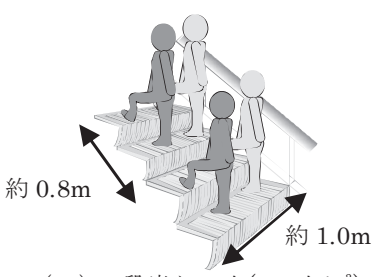

（1） 2 段当り 2 人 $\left(2.5\right.$ 人 $\left./ \mathrm{m}^{2}\right)$

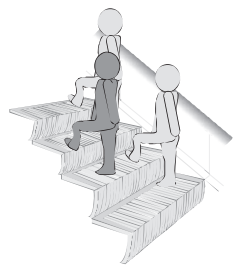

（2） 2 段当り 1.6 人 $\left(2.0\right.$ 人 $\left./ \mathrm{m}^{2}\right)$

図 5 エスカレーター歩行時の歩行者の様子 


\section{（2）歩行者流量（表 9)}

エスカレータ上の歩行者流量 $\mathrm{Mv}($ 人/s) は下式で与えられるが、実 験結果から Mv を計算すると、表 9 のように、歩行者の移動速度に ほぼ比例する。

$\mathrm{Mv}=\mathrm{PeWVp}=\mathrm{PeW}(\mathrm{Ve}+\mathrm{Vw})$ ・・式(1)

$\mathrm{Pe} \quad$ 歩行者密度 $\left(\right.$ 人 $\left./ \mathrm{m}^{2}\right)$

Wエスカレータステップ幅 $(\mathrm{m})$

$\mathrm{Vp}$ エスカレータ上の歩行者の移動速度 $(\mathrm{m} / \mathrm{s})$

$\mathrm{Ve}$ エスカレータ走行速度 $(\mathrm{m} / \mathrm{s})$

$\mathrm{Vw}$ エスカレータ上の歩行速度 $(\mathrm{m} / \mathrm{s})$

表 9 エスカレータ入口通過人数と歩行者流量の比較 (短距離エスカレータ $[\mathrm{W}=1.0 \mathrm{~m}]$ )、ケース 18,19

\begin{tabular}{|l|l|l|}
\hline 項目 & 停止時 & 稼動時 \\
\hline 入口通過人数実測值, 人 $/ \mathrm{s}$ & 1.16 & 1.78 \\
\hline 歩行者密度実測值 $(\mathrm{Pe})$, 人 $/ \mathrm{m}^{2}$ & 1.98 & 1.95 \\
\hline 歩行速度実測值 $(\mathrm{Vw}), \mathrm{m} / \mathrm{s}$ & 0.51 & 0.42 \\
\hline エスカレータ走行速度 $(\mathrm{Ve}), \mathrm{m} / \mathrm{s}$ & 0.00 & 0.50 \\
\hline 歩行者流量 $(\mathrm{Mv}=\mathrm{PeW}(\mathrm{Vw}+\mathrm{Ve}))$, 人 $/ \mathrm{s}$ & 1.01 & 1.78 \\
\hline
\end{tabular}

エスカレータ入口通過人数が停止時に少ないのは、入口手前の水 平面上の歩行速度の方がエスカレータ上の移動速度よりも大きく、 入口で滞留が発生するためである。シニアの混在率や分布が変化す れば群集移動速度が変化し、歩行者流量も変化すると考えられるが、 3.1(3)の考察より、本実験のシニア混在率 24\%では、ほぼ、歩行速 度の遅い集団の影響が群集全体を支配すると判断できたため、Vw の観測值は、本実験条件のもとでは、移動速度の上限と判断できる。 また、3.2(1)の考察より、Peの観測值はエスカレータ上を円滑に歩 行できる密度の上限を表すと解釈でき、よって、表 9 に示す停止時 の歩行者流量は、本実験条件のもとでは、その上限に達している。 また、停止時のエスカレータ上の歩行者流量は入口通過人数より少 ないが、入口手前からエスカレータ斜路部分まで進む間に歩行速度 が増加して歩行者密度が低下し、エスカレータ上を一定人数が通過 する時間が増加するためである。エスカレータ稼動時は、入口通過 人数とエスカレータ上の歩行者流量が一致し、入口手前にも停止時 のような滞留は認められなかったが、Pe 值は停止時とほとんど変わ らないから、稼動時の歩行者流量の観測值も、ほぼその上限に達し ていると解釈できよう。

\section{3 エスカレータ入口の有効流動係数}

\section{（1）エスカレータの走行速度と入口の有効流動係数の関係}

エスカレータ入口での単位幅当たり通過人数は、エスカレータ停 止時は $1.1 \sim 1.2$ 人 $/(\mathrm{s} \cdot \mathrm{m})$ ）稼動時は $1.6 \sim 1.8$ 人 $/(\mathrm{s} \cdot \mathrm{m})$ であった (表 7 、 配置 A)。前節の考察より、この単位幅当り通過人数は入口先方の工 スカレータ上の歩行者流量が制約されることによる有効流動係数を 表すと解釈できる。更に、エスカレータ入口の有効流動係数はエス カレータ上の歩行者の移動速度に支配され、前項のように、入口通 過可能な人数は、エスカレータ上の歩行者流量をやや上回るとする 之、有効流動係数 Fe は、入口通過人数が、式(1)右辺の歩行者密度 に、その上限值 $\mathrm{Pec}=2.0$ 人 $/ \mathrm{m}^{2}$ を代入して計算した $\mathrm{Mv}$ 值に一致する ように設定すれば、安全側の計画を誘導する推定值が得られると考 えられる。即ち、

$\mathrm{Fe}=\mathrm{Pec}(\mathrm{Ve}+\mathrm{Vw})=2.0\left(\mathrm{Ve}+\mathrm{Vw}_{\mathrm{w}}\right)$

但し、式(2)によると、エスカレータ走行速度を増加させると $\mathrm{Fe}$ が単純増加することになるが、 Ve+Vw が増加すれば、 $\mathrm{PecW}(\mathrm{Ve}+\mathrm{Vw})$ が入口で通過可能な人数の限界を超えて歩行者密度が低下するはず である。エスカレータの走行速度が現状より著しく増加するとは考 え難いが、本研究で対象とするシニアが混在した群集に比べると、 健常者だけの群集の歩行速度は大きくなるであろうから、今後は、 エスカレータの一般的な稼動条件の範囲で、群集の状態によって、 Fe 值が更にどう変化するかを把握することが望まれる。

(2) エスカレータの長さと入口の有効流動係数の関係（図 6、図 7) 表 7 のように、エスカレータ入口での単位幅当たり通過人数は、 長距離エスカレータの方が短距離エスカレータよりも、停止時・稼 動時とも 8〜 9\%小さい結果となった。群集歩行速度は、表 6 のよう に短距離エスカレータの方が長距離エスカレータよりやや小さいの で、このエスカレータ入口での単位幅当たり通過人数の違いは、短 距離エスカレータの方が平均歩行者密度が高かったことを意味する と解釈できる。そこで、両方のエスカレータ稼動時の入口付近の長 さ $1.2 \mathrm{~m}$ の部分の密度の時間变化の様子を整理して、図 6 に示す。 図 7 中の時刻は、先頭が測定区域に入った瞬間を基準とする経過時 間である。群集密度が上下することに着目すると、短距離エスカレ

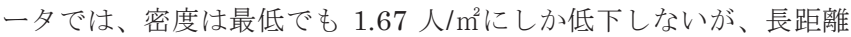

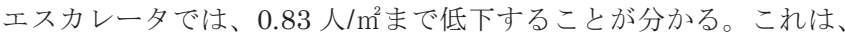
長距離エスカレータでは、シニア混じりの群集が歩行する間にシニ アの粗密が生じ、シニアが多い部分では追い抜きが困難になるため、 群集が、シニアの粗密に対応するグループに分かれる傾向を示すの に対し、短距離エスカレータでは、歩行時間が短いため、群集の分
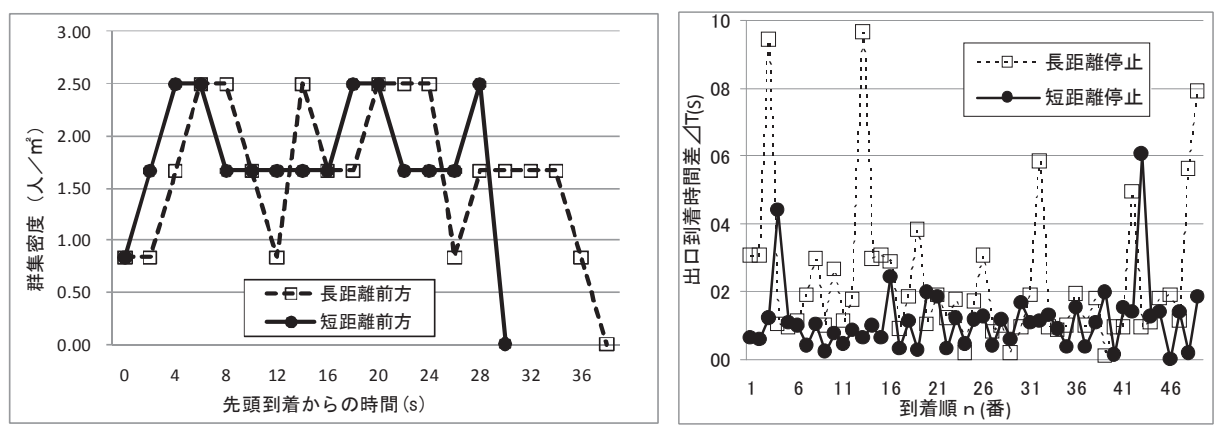

図 6
エスカレータ稼動時の入口付近群集密度の変化 図 7 (a) 出口到着順の到着時間差(停止)

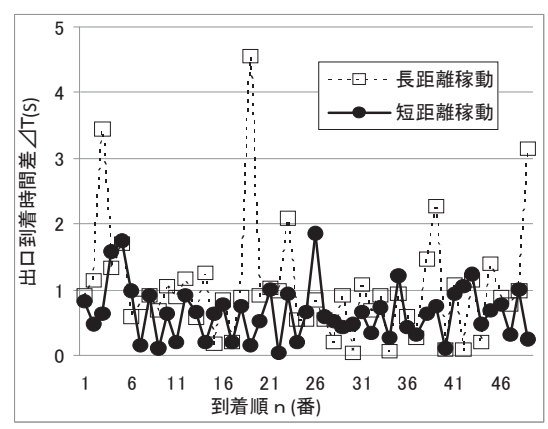

図 7 (b) 出口到着順の到着時間差(稼働) 
裂までには至らず、全体が、高い密度で歩行する傾向を示すためと 考えられる。エスカレータ出口に被験者が到着する時間間隔 $(\Delta T n$ $=\mathrm{T}_{n+1}-\mathrm{T}_{\mathrm{n}}, \mathrm{Tn}: \mathrm{n}$ 番目に到着した被験者の到着時間)が、エスカレ 一タの長さの違いによってどう変化するかを稼動・停止両条件につ いて比較すると図 7 のようになるが、長距離エスカレータでは、 5 秒を超える到着間隔が頻繁に発生し、それらの間の被験者がグルー プを形成しているのに対し、短距離エスカレータでは、目だって長 い到着間隔は、集団の先頭と最後部の付近以外には見られない。こ のように、シニアが混在する群集の入口通過人数が、エスカレータ の長さによって変わるのは、エスカレータ上の群集歩行の特性に起 因寸ると考えられるので、有効流動係数は、エスカレータの長さに 依存すると結論できる。なお、ステップ幅は長距離エスカレータの 方が約 $2.5 \%$ 大きいが、通過をより容易にするほどの差とはいえない。 （3）入口前の手摺設置・整列乗り入れが有効流動係数に及ぼす影響

手摺を設置(配置 $A^{\prime}$ ) したり、整列乗り入れ(配置 B) した場合、表 7 に示すように、エスカレータ入口での単位幅当り通過人数はやや低 下し、低下率は稼動時に大きくなった。これは、手摺・整列乗り入 れにより、入口手前の群集の歩行者流量が、団塊型の配置 $\mathrm{A}$ より低 下寸るためと考えられる。

特に、エスカレータ稼動時は、入口手前で群集が整列する場合の 入口手前の群集歩行速度が、エスカレータ上の移動速度より小さい から、エスカレータ入口通過人数は、エスカレータ手前の群集の歩 行者流量に支配されると考えられる。一方、エスカレータ停止時に は、水平面のシニアの群集歩行速度が $0.6 \sim 1.0 \mathrm{~m}^{3)}$ と本実験におけ るエスカレータ上の歩行速度より大きいことから、エスカレータ手 前の健常者を含む群集歩行速度は、エスカレータ上よりも大きく、 エスカレータ入口通過人数は、手摺・整列等のない場合と同様、エ スカレータ上の搬送可能流量によって決まると考えられる。表 7 に はエスカレータ停止時と稼働時のエスカレータ入口での単位幅当り 通過人数を示したが、停止時のエスカレータ入口での単位幅当り通 過人数に対する手摺設置・整列乗り入れの影響が軽微なのは、その ためと考えられ、シニアを片側配置した時にエスカレータ入口での 単位幅当り通過人数が顕著に増加するのは、エスカレータ上でシニ アの追い抜きが容易になり、シニアがランダムに存在する場合に比 べて搬送可能流量が増大寸るためである。

\section{4 階段・エスカレータの歩行速度の比較と併設時の経路選択 （1）階段・エスカレータの歩行速度の比較（図 8)}

階段と併設されている短距離エスカレータにおいて、エスカレー 夕停止時の移動速度と階段の移動速度を被験者毎に比較して図 8 に 示す。単独歩行時(ケース 10)は、階段を一段飛ばしで歩いた場合を 除いて、健常者もシニアも、移動速度が階段(ケース 7) と大きくは変 わらないが、78\%の被験者において、停止エスカレータ歩行の方が やや速い結果となった(図 8 (a))。エスカレータは蹴上げ寸法が大き い分、一段で上昇できる距離が大きく、また、階段のように踊り場 がないために歩行のテンポが一定である点は、特に健常者に対して は歩行速度を高める要因になっていると考えられる。エスカレータ を歩行して上るという行為自体は、一般に予想されるほど困難では ないことが分かった。なお、シニア以外の階段平均歩行速度は $0.54 \mathrm{~m} / \mathrm{s}$ であるが、階段の群集上昇歩行の既往実験では、健常者の 歩行速度は、 $0.46 \mathrm{~m} / \mathrm{s}$ (文献 $4 \cdot 5$ ) 注 2) $^{2} 0.56 \mathrm{~m} / \mathrm{s}$ (文献 6) 注 3) となって
おり、文献 $4 \cdot 5$ が幅の狭い階段を使ったことにより、追い抜きが 困難になったための歩行速度低下が認められる点を除き、本実験と 大きな差はみられない。

一方、群集歩行時(ケース 18)は、逆に、停止エスカレータの方が、 階段(ケース 9 )より移動速度が遅い結果となった(図 $8(\mathrm{~b})$ が、今回実 験を行った施設は、エスカレータのステップ幅が約 $1 \mathrm{~m}$ であったの に対し、階段幅は $2.5 \mathrm{~m}$ と広く、階段の方がエスカレータに比心゙、 歩行者密度も低く各自の自由な歩行が可能であり、追い抜き等もし 易かったことに起因すると考えられる。階段であれエスカレータで あれ、群集歩行速度は、遅い歩行者を追い抜けるかどうかに大きく 支配されるが、エスカレータはステップ幅がほぼ固定されているの で(2名用なら約 $1.0 \mathrm{~m}) 、$ 幅が調整可能な階段に比べ、この影響が顕 著に現れると解釈できる。

\section{（2）エスカレータ・階段併設時の経路選択（図 9)}

エスカレータと階段の選択は、図 9 のように概被験者の目前の ものが選択された。この傾向は、エスカレータ停止時と稼動時とで 特に変化はなく、更に、シニアの経路選択も、稼動時を含めて同様 であった。こうした結果になったのは、高低差実験が $5.7 \mathrm{~m}$ と比較 的小さく、階段を上ってもあまり負担にならないこと、また、結果 から見て被験者の行列とエスカレータ及び階段の入口の間隔が短く、 経路選択が制約された可能性があることも影響していよう。

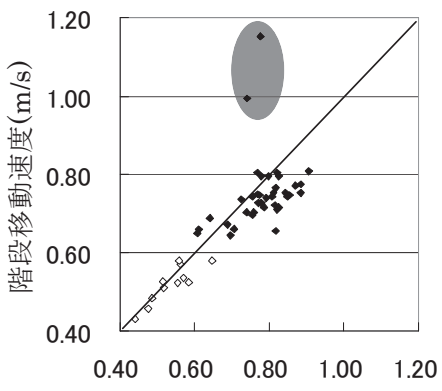

停止エスカレータ移動速度 $(\mathrm{m} / \mathrm{s})$

(a) 単独歩行時(ケース 7 と 10)

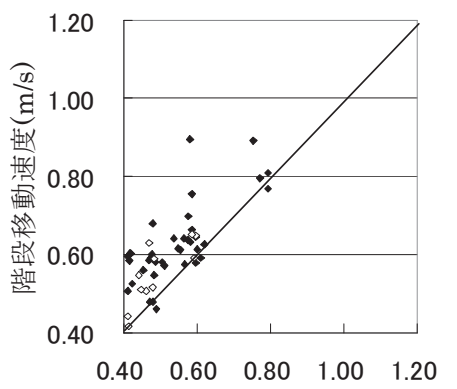

停止エスカレータ移動速度 $(\mathrm{m} / \mathrm{s})$

(b) 群集歩行時(ケース 9 と 18)
階段を一段飛ばしで歩行した被験者

図 8 階段と停止エスカレータの比較

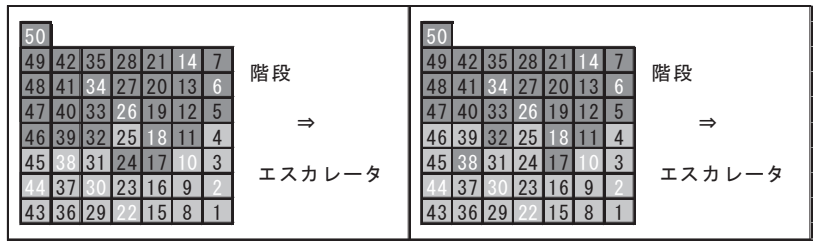

1 階段選択者 1 エスカレータ選択者 ※白抜きはシニア

エスカレータ停止時(ケース 14)エスカレータ稼動時(ケース 15)

図 9 経路の選択

\section{4. 結論}

本実験より、エスカレータを利用する上方への避難について、以 下のように結論できる。

（1）エスカレータ停止時の単独歩行速度は、健常者が 0.78 $0.79 \mathrm{~m} / \mathrm{s}$ 、シニアが約 $0.50 \sim 0.53 \mathrm{~m} / \mathrm{s}$ であり、階段の上方歩行 時と特に変わらない。

（2）エスカレータ稼動時の単独歩行速度は、健常者が 0.71 $0.76 \mathrm{~m} / \mathrm{s}$ 、シニアが約 $0.43 \mathrm{~m} / \mathrm{s}$ と、停止時に比べて、各々僅か 
に低下する。

（3）エスカレータ上の健常者の歩行速度は、高低差 $22 \mathrm{~m}$ までの範囲 では歩行距離によって低下寸ることはない。インスタントシニ アについても同様であったが、疲労やステップ高さが大きいこ とが高齢者の長距離上昇歩行に及ぼす影響は今後、解明する必 要がある。

（4）エスカレータのステップ幅は円滑な追い抜きにはやや不足する こと、また、シニアが並ぶと追い抜きができなくなることから、 歩行速度の異なる集団が混在する場合、群集歩行速度は、歩行 速度の遅い集団の歩行速度に近くなる。歩行速度の遅い歩行者 がエスカレータ上で並ぶ可能性は、その混在率が高いほど高ま るから、歩行速度の異なる集団が混在することによる群集避難 行動への影響は、その混在率にも依存すると考えられる。本実 験では、インスタントシニアの混在率が $24 \%$ と、現在の鉄道利 用者の高齢者率より高めになっており、避難誘導をより合理的 にするには、健常者のみの群集を含め、混在率と群集避難行動 への影響の関係をより詳しく把握する必要があろう。

（5）インスタントシニアが混在する群集のエスカレータ入口の有効 流動係数は、エスカレータ停止時で約 1.16 人/(s・m)、稼動時で 1.78 人 $/(\mathrm{s} \cdot \mathrm{m})$ となり、エスカレータ上の歩行者の移動速度にほ ぼ比例する。即ち、エスカレータを稼動して避難に利用できれ ば、移動速度が増加するだけでなく、有効流動係数の増加によ る避難可能人数の増加を期待できることになる。

（6）エスカレータ入口手前の水平面に手摺りを設けると、エスカレ 一夕稼動時には、手摺りがない場合に比べて入口通過人数が低 下寸る。これは、群集が整流されると、水平面上の歩行速度が 稼動中のエスカレータ上の移動速度よりも低下し、入口手前に 滞留が生じなくなるためである。

（7）エスカレータ入口の有効流動係数は、歩行速度の異なる集団が 混在する群集では、エスカレータが長いほど、低下傾向を示す。 これは、長距離歩行の間に遅い歩行者の分布に粗密が生じ、追 い抜きが極めて困難な場所が局所的に発生することによって、 群集全体に粗密が生じるためである。

（8）歩行速度の遅い集団の混在率が高い場合、遅い集団をエスカレ ータの片側に集中させれば、エスカレータ上の歩行者流量は目 だって増加する。

（9）エスカレータを円滑に上昇歩行する時の歩行者密度の上限は 約 2.0 人/ $/ \mathrm{m}^{2}$ である。

（10）エスカレータ手前に手摺を設けたり、予め歩行者を 2 列に整 列させたりすると、群集が団塊状になる場合に比べ、入口手前 の歩行者流量が減少し、エスカレータ人口の通過人数が減少す る。この影響は、エスカレータ稼動時に特に大きいが、これは、 エスカレータ稼動により、入口の有効流動係数が上昇し、手前 の単位幅当り水平歩行者流量が有効流動係数に及ばなくなるた めと考えられる。

（11）歩行者を 2 列に整列させ、シニアをその一方に集中させた場 合、健常者のみの列の群集歩行速度は $0.68 \mathrm{~m} / \mathrm{s}$ 之、健常者単独 歩行時にやや接近する。入口手前の健常者の水平歩行速度も上 昇するため、エスカレータ停止時の入口通過人数は、シニア混 在時に比べ、顕著に増加する。

以上、本実験では、歩行速度の遅い歩行者を含む群集についてエ スカレータによる上昇避難の可能性を検討するための基本的な諸量 を把握し、エスカレータを避難方向に稼動させて活用することの効 果について見通しが得られた。本実験では、群集におけるシニアの 割合を一定 $(24 \%)$ としたが、エスカレータ上の群集歩行性状は、シ ニアの割合に大きく影響されると予想されるため、シニア率と群集 歩行行動の関係の把握等も今後の重要な課題である。一方、エスカ レータの避難利用には、避難方向と逆に走行するエスカレータの停 止、その逆走への転換が必要である。このうち、エスカレータを停 止することは、エスカレータを階段代わりに避難に利用する場合も 必要であり、これらを安全に行うための装置の性能と運転方法の検 討も必要である。また、本実験では、地下からの避難を想定して上 昇避難だけを考慮したが、地上駅舎等にも見られるエスカレータの みの昇降路では、下方避難にも使われる可能性があるから、下方避 難時の歩行行動についても同様の検討が必要である。

\section{謝辞}

本実験は、セコム科学技術振興財団の助成研究「都心地下空間の セキュリティ・ハザードマップ」により実施し、分析の一部は、科 学研究費補助金「都心地下空間における街区・地下道一体型防災計 画手法の開発」により実施した。実験施設の利用については、株式 会社東京ビッグサイトに多大な協力を頂きました。実験・分析にあ たり、当時、早稲田大学大学院生の平川和孝、武盛功太、蛇石貴宏、 盧韻琴他、早稲田大学長谷見研究室の各位に多大な協力をいただき ました。

\section{参考文献}

1）森山修治・岡田尚子・長谷見雄二・他：エスカレータを用いた避難行動特 性に関する実験研究, 日本建築学会大会学術講演梗概集, A-2 分冊 pp.67-70,2008.9

2）門倉博之, 佐藤歩, 岡部弘志, 西田幸夫, 辻本誠, 関沢愛 : 停止エスカレータ 一における避難行動特性に関する実験的研究 その 3 エスカレーターの高 低差と歩行速度, 日本火災学会研究発表会梗概集, pp.68-69,2008.5

3）古川容子, 土屋伸一, 稲原攝雄, 長谷見雄二：高齢者擬似体験用具による高 齢者の群集時歩行行動の再現可能性 高齢者が混在する群集の避難行動モ デル化に関する研究：日本建築学会計画系論文集, N0.581, pp.9-14,2004.7

4) 土屋伸一, 森山修治, 浜暁也, 渡辺大地, 長田悠平, 小川純子, 神忠久, 長谷見雄二: 津波避難ビルにおける階段歩行特性に関する実験研究 その 1 実験概要及び階段上昇時の単独歩行特性, 日本建築学会大会学術講演 梗概集, E-1 分冊, pp905-906,2006

5）森山修治, 長田悠平, 土屋伸一, 小川純子, 浜暁也, 神忠久, 渡辺大地, 長谷見雄二：津波避難ビルにおける階段歩行特性に関する実験研究 その 2 階段上昇時の群集歩行特性, 日本建築学会大会学術講演梗概集, E-1 分 冊, pp907-908,2006

6）萩原一郎, 北後明彦：地下空間からの避難計画 階段における連続 昇降実験, 日本建築学会大会学術講演梗概集, A 分冊, pp1327-1328,1992

注1）歩行速度は、エスカレータ出入り口の水平路を除いた斜路部分のみで 測定した結果である。

注2）被験者 50 名中インスタントシニア役 12 名の群集で実験を行った。シ ニア役の配置は本論文の実験と類似したランダム配置である。歩行速 度は斜面速度を表す。

注3）論文内では、歩行速度が水平方向 $0.5 \mathrm{~m} / \mathrm{s}$ 、垂直方向 $0.26 \mathrm{~m} / \mathrm{s}$ と表わさ れているので、斜面速度に換算した。被験者数 23 名で、全員が 50 歳 未満である。 